\title{
SPATIAL DISTRIBUTION OF RADIOCARBON IN THE SOUTHWESTERN JAPAN/ EAST SEA IMMEDIATELY AFTER BOTTOM WATER RENEWAL
}

\author{
Takafumi Aramaki ${ }^{1,2} \cdot$ Shinichi S Tanaka ${ }^{1}$ Seiko Kushibashi ${ }^{1} \cdot$ Young-Il Kim $^{3} \bullet$ \\ Chang-Jun Kim ${ }^{3}$ Gi-Hoon Hong ${ }^{3}$ Tomoharu Senjyu ${ }^{4}$
}

\begin{abstract}
In April 2001, immediately after bottom water renewal in the Japan/East Sea, 7 vertical profiles of radiocarbon were obtained from the area, including the Japan Basin and the Tsushima/Ulleung Basin. The bottom water $\Delta^{14} \mathrm{C}$ of the Tsush$\mathrm{ima} /$ Ulleung Basin increased by 24\% during 1979-2001 and was 10-15\%o higher than the values reported for the Japan Basin and Yamato Basin during 1995-2002. Within the depth interval $800-2000 \mathrm{~m}, \Delta^{14} \mathrm{C}$ values at the southernmost station in the Japan Basin were much higher than at other stations, with the maximum difference in $\Delta^{14} \mathrm{C}$ values being more than $50 \%$. Based on a combination of physical observations with analysis of the $\Delta^{14} \mathrm{C}$ data, we concluded that the bottom water, which was formed by the sinking of surface water off Vladivostok, Russia, in late January-early February of 2001, had been widely distributed to depths below $2000 \mathrm{~m}$ within the southernmost Japan Basin in a timespan shorter than 2 months. However, there was no evidence that the water had been transported into the Tsushima/Ulleung Basin during the same time interval.
\end{abstract}

\section{INTRODUCTION}

The Japan/East Sea is an almost landlocked marginal sea in the northwest Pacific Ocean (Figure 1). Its surface area and volume are about $1.0 \times 10^{6}$ and $1.7 \times 10^{6} \mathrm{~km}^{3}$, respectively, and reaches a maximum depth of more than $4 \mathrm{~km}$. The sea is separated from the northwest Pacific by the Japanese Islands and is connected to the northwest Pacific, East China Sea, and Okhotsk Sea through 4 straits. Because these straits have shallow sill depths $(<150 \mathrm{~m})$, the surface layer of the sea is occupied by Tsushima Warm Current Water (TWCW), which flows from the East China Sea through the Tsushima Strait, and the deep water below the TWCW is completely isolated from Pacific deep water. This deep water, termed the Japan Sea Proper Water (JSPW, e.g. Suda 1932), consists of 3 water masses: the upper JSPW, deep water, and bottom water (e.g. Sudo 1986). The bottom water is characterized by extremely homogeneous vertical distributions of temperature and chemical variables such as dissolved oxygen (Gamo and Horibe 1983). The origin of the water is the surface water in the northern Japan/East Sea, because evaporation and/or freezing at the sea surface during the winter causes the surface water to become dense enough to sink toward the bottom (Sudo 1986). The bottom water is therefore colder and richer in dissolved oxygen than the deep water in the northwest Pacific Ocean.

The warming evident throughout the global ocean is also clearly apparent in the Japan/East Sea, which has warmed by $0.1^{\circ} \mathrm{C}$ at a depth of $1000 \mathrm{~m}$ and by $0.05^{\circ} \mathrm{C}$ below $2500 \mathrm{~m}$ since the $1960 \mathrm{~s}$ (Kim et al. 2001). The salinity at these depths has also changed, by 0.06 psu per century at depths of $300-$ $1000 \mathrm{~m}$ and by 0.02 psu per century below $1500 \mathrm{~m}$ (Kwon et al. 2004). The bottom water has therefore barely been ventilated since the 1960s or earlier because global warming has probably slowed deep convection in the sea (e.g. Gamo 1999). Consistent with this hypothesis is the fact that the dissolved oxygen concentration of the water has markedly decreased from the 1930 s to 2000 at a rate of $\sim 0.8 \mathrm{~mol} / \mathrm{kg} / \mathrm{yr}$ (Gamo et al. 1986; Minami et al. 1999). In contrast, newly formed bottom water was found in the northwestern Japan/East Sea in the summer of 2001 after the severe winter of 2000-

\footnotetext{
${ }^{1}$ Center for Environmental Measurement and Analysis, National Institute for Environmental Studies, 16-2, Onogawa, Tsukuba, Ibaraki 305-8506, Japan.

${ }^{2}$ Corresponding author. Email: ara@nies.go.jp.

${ }^{3}$ Korea Institute of Ocean Science \& Technology, 1270 Sasong, Ansan 426-744, Korea.

${ }^{4}$ Research Institute for Applied Mechanics, Kyushu University, 6-1 Kasuga-koen, Kasuga, Fukuoka 816-8580, Japan.
}

(C) 2013 by the Arizona Board of Regents on behalf of the University of Arizona

Proceedings of the 21 st International Radiocarbon Conference edited by A J T Jull \& C Hatté

RADIOCARBON, Vol 55, Nr 2-3, 2013, p 1675-1682 


\section{T Aramaki et al.}

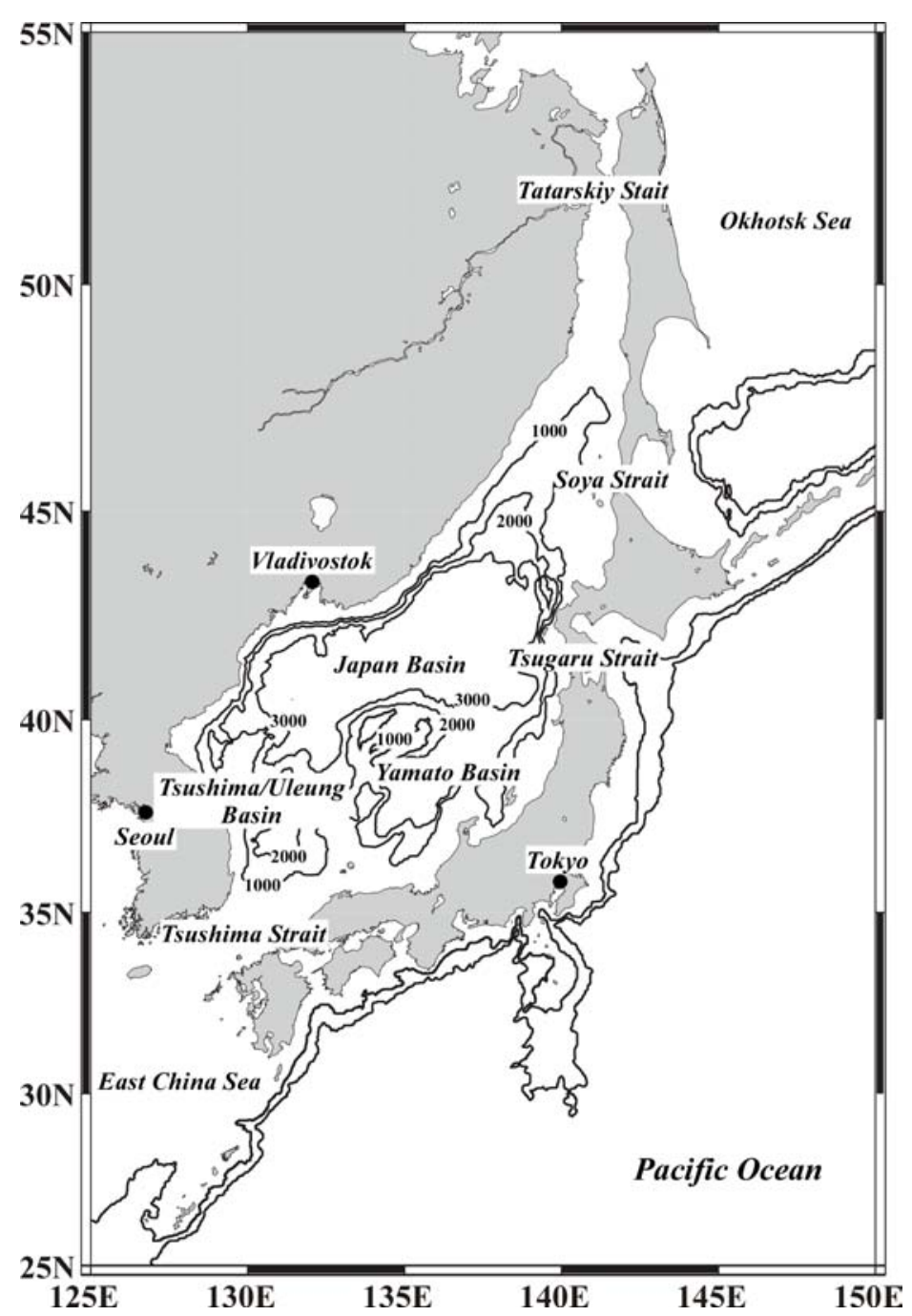

Figure 1 Bathymetric chart of the Japan/East Sea. Contour lines indicate depths (m).

2001 (Senjyu et al. 2002; Kim et al. 2002). The new bottom water is characterized by a low temperature, high salinity, and high dissolved oxygen concentration compared to the old bottom water. Hydrographical analysis indicated that the bottom water was formed south off Vladivostok, Russia, and the formation event occurred in late January-early February of 2001 (Senjyu et al. 2002).

In April 2001, immediately after this renewal of bottom water, the Korea Ocean Research and Development Institute (KORDI until 30 June 2012 and Korea Institute of Ocean Science \& Technology [KIOST] since 1 July 2012) carried out a hydrographic survey in the southwestern Japan/ East Sea south of the area of bottom water formation. The survey produced 7 vertical profiles of radiocarbon from the area, including the Japan Basin and the Tsushima/Ulleung Basin. In general, the amount of ${ }^{14} \mathrm{C}$ in the dissolved inorganic carbon (DIC) of the ocean is higher in the surface layer and decreases with water depth (e.g. Östlund and Stuiver 1980; Key et al. 1996) because ${ }^{14} \mathrm{C}$ enters the ocean only through air-sea $\mathrm{CO}_{2}$ gas exchange and the concentration subsequently decreases due 
to radioactive decay and mixing with "old," ${ }^{14} \mathrm{C}$-deficient seawater. Bottom water renewal in the Japan/East Sea increases both the activity of ${ }^{14} \mathrm{C}$ in the DIC and the dissolved oxygen concentration of the bottom water. This article reports the spatial distribution of ${ }^{14} \mathrm{C}$ activity $\left(\Delta^{14} \mathrm{C}\right)$ in the southwestern Japan East Sea in April 2001 and discusses the behavior of newly formed bottom water in this area.

\section{SAMPLING AND METHODS}

The observations in the Japan/East Sea area were carried out during a KORDI hydrographic survey onboard the R/V Eardo during 10-25 April 2001. During the survey, we conducted a meridional transect for ${ }^{14} \mathrm{C}$ that consisted of 7 stations (G01, G03, G06, G09, G12, G15, and G18) along $130.5^{\circ} \mathrm{E}$ from the Tsushima/Ulleung Basin to the southernmost Japan Basin (Figure 2). Measurements of salinity, temperature, and dissolved oxygen were made using a conductivity-temperaturedepth (CTD) profiler system with a dissolved oxygen sensor. Seawater samples for chemical measurements including ${ }^{14} \mathrm{C}$ and dissolved oxygen were collected from the surface to the bottom by using Niskin bottles attached to a CTD with rosette multi-sampler (CTD/RMS).

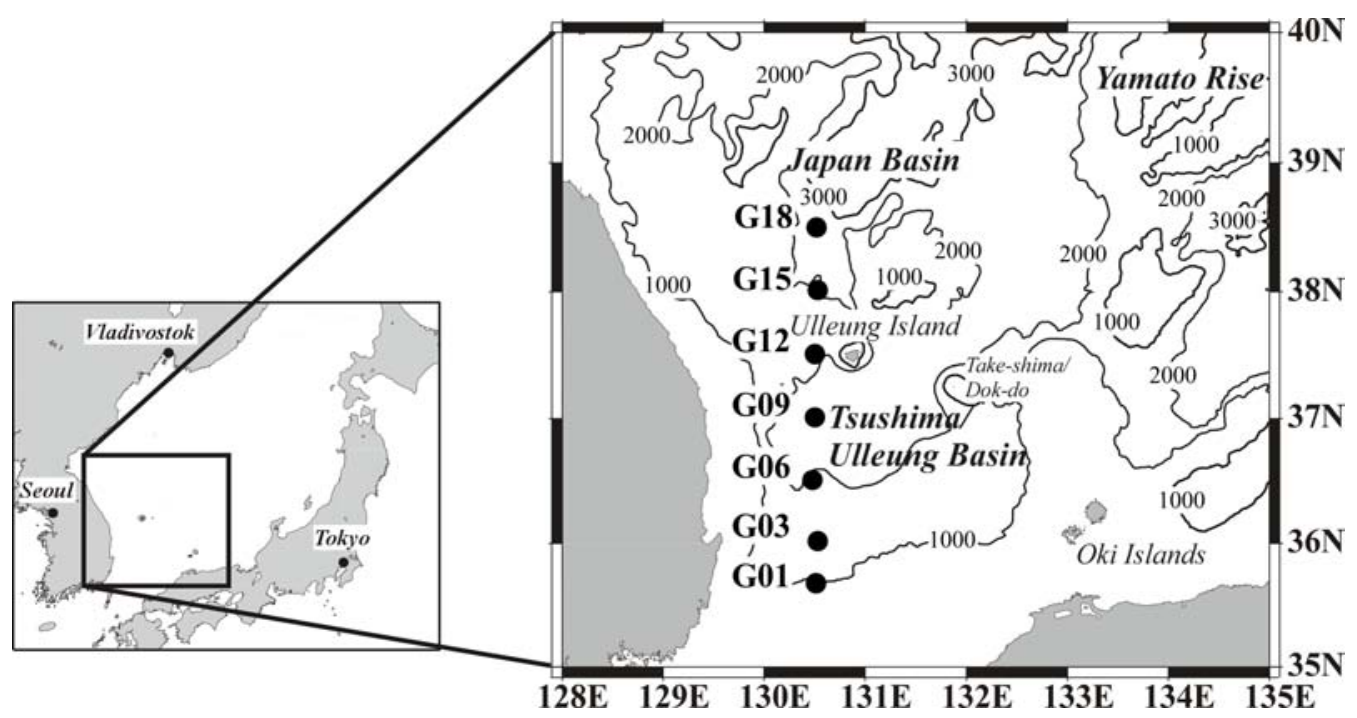

Figure 2 Sampling stations in the southwestern Japan/East Sea

The dissolved oxygen sensor of the CTD system was calibrated with the Niskin bottle dissolved oxygen concentrations, which were measured onboard by the modified Winkler technique (Carpenter 1965; Dickson 1995). The seawater samples for ${ }^{14} \mathrm{C}$ measurements were stored in 500 -mL glass bottles after adding $500 \mu \mathrm{L}$ of saturated $\mathrm{HgCl}_{2}$ solution onboard the research vessel to stop biological activity. In our laboratory, the dissolved inorganic carbon in the samples was evolved as $\mathrm{CO}_{2}$ gas by adding $4 \mathrm{~mL}$ of $100 \% \mathrm{H}_{3} \mathrm{PO}_{4}$. The gas was collected cryogenically by purging with pure $\mathrm{N}_{2}$ gas in a vacuum system (Aramaki et al. 2000). The $\mathrm{CO}_{2}$ carbon was reduced to graphite with pure $\mathrm{H}_{2}$ gas over an iron catalyst at $650{ }^{\circ} \mathrm{C}$ (Kitagawa et al. 1993). The ${ }^{14} \mathrm{C} /{ }^{12} \mathrm{C}$ ratios of the sample graphite were measured at the Tandetron AMS Facility in the Mutsu Office of the Japan Atomic Energy Agency (Aramaki et al. 2000). ${ }^{14} \mathrm{C}$ results are expressed as $\Delta^{14} \mathrm{C}$ (Stuiver and Polach 1977; Stuiver 1983). The typical analytical error of the ${ }^{14} \mathrm{C}$ values was about $\pm 4 \%$ based on the $1 \sigma$ value of the counting statistics. 


\section{T Aramaki et al.}

\section{RESULTS AND DISCUSSION}

The vertical profiles of $\Delta^{14} \mathrm{C}$ values at the 7 stations in the southwestern Japan/East Sea in April 2001 (Figure 3) each showed a maximum in the surface water and a monotonic decrease with depth down to $1500 \mathrm{~m}$. The $\Delta^{14} \mathrm{C}$ values below $1500 \mathrm{~m}$ were vertically homogeneous and averaged $-50 \pm$ $7 \%$, except for the data at station G18. The water mass below $1500 \mathrm{~m}$ is the bottom water described by Gamo and Horibe (1983), who reported that the $\Delta^{14} \mathrm{C}$ of the bottom water in the southernmost portion of the Japan Basin $\left(38^{\circ} 23^{\prime} \mathrm{N}, 132^{\circ} 49^{\prime} \mathrm{E}\right)$ was $-74 \pm 6 \%$ in July 1979 . The bottom water $\Delta^{14} \mathrm{C}$ increased by $24 \%$ during 1979-2001 because of deep ventilation of surface water, a phenomenon characteristic of the East Sea. In addition, the $\Delta^{14} \mathrm{C}$ value was $10-15 \%$ higher than the values reported for the Japan Basin and Yamato Basin during 1995-2002 (Kumamoto et al. 1998; Aramaki et al. 2007; Kumamoto et al. 2008). Therefore, new bottom water formed in the northwestern Japan/ East Sea may in general be transported more quickly throughout the deep layer of the Tsushima/ Ulleung Basin compared to other basins.

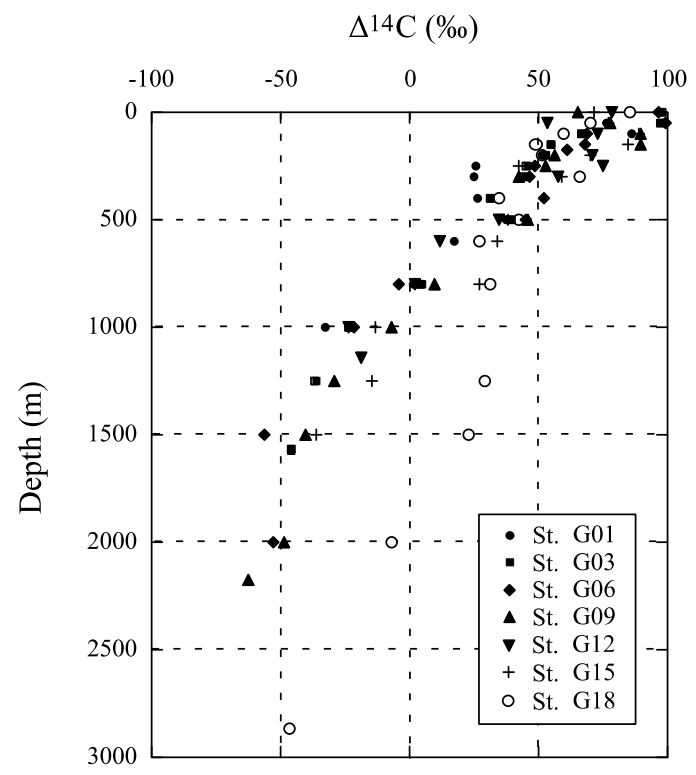

Figure 3 Vertical profiles of $\Delta{ }^{14} \mathrm{C}$ in the southwestern Japan/ East Sea during April 2001.

There was a unique feature of the vertical profile at the southernmost Japan Basin station (G18). In the 800-2000 m depth interval, the $\Delta^{14} \mathrm{C}$ values were clearly higher at station G18 compared to the other stations, with a maximum difference of $\Delta^{14} \mathrm{C}$ being more than $50 \%$. The meridional sections of $\Delta^{14} \mathrm{C}$, dissolved oxygen, and potential temperature along $130.5^{\circ} \mathrm{E}$ are shown in Figure 4. Although potential temperature varied little within the observational area, dissolved oxygen was slightly higher in isobaths below $500 \mathrm{~m}$ at station G18 compared to other stations. These results suggest that the bottom water newly formed in late January-early February of 2001 (Senjyu et al. 2002) had flowed southward to the southernmost Japan Basin station within just 2 months. Vertical profiles of $\Delta^{14} \mathrm{C}$, potential density, and isopycnic potential vorticity (IPV) at station G18 are shown in Figure 5. Potential vorticity is a dynamically conservative property corresponding to fluid angular momentum and is approximated by IPV in areas with low flow and low relative vorticity (Talley et al. 2011). The IPV is defined by the following equation: 


$$
I P V=\frac{f}{\rho_{\theta}} \frac{\partial \rho_{\theta}}{\partial z}
$$

where $\rho_{\theta}$ and $f$ are potential density and the Coriolis parameter, respectively. The value of $f$ is determined by the following equation:

$$
f=2 \Omega \sin \varphi
$$

where $\Omega$ and $\varphi$ are the angular velocity and latitude, respectively. The IPV at station G18 decreased with water depth and had a local minimum near a pressure of 2000 decibars (dbar) and a local maximum near $2200 \mathrm{dbar}$. The IPV below 2200 dbar then decreased drastically because of the homogeneity of potential density. These results suggest that the water column between 2000 and $2200 \mathrm{dbar}$ was a boundary between 2 water masses. This fact is also apparent from the slight inflection of the potential density vertical profile near $2000 \mathrm{dbar}$. Because the $\Delta^{14} \mathrm{C}$ of the deepest layer at station G18 was $-47 \pm 4 \%$, similar to the value of the bottom water in the Tsushima/Ulleung Basin, the water mass below the boundary is regarded as "old" bottom water. The water mass with the high $\Delta^{14} \mathrm{C}$ and high oxygen concentration above the boundary must therefore have been newly formed bottom water. New bottom water, formed by the sinking of surface waters in 2001, was widely distributed at depths below $2000 \mathrm{~m}$ in the southernmost Japan Basin within a timespan of $<2$ months.
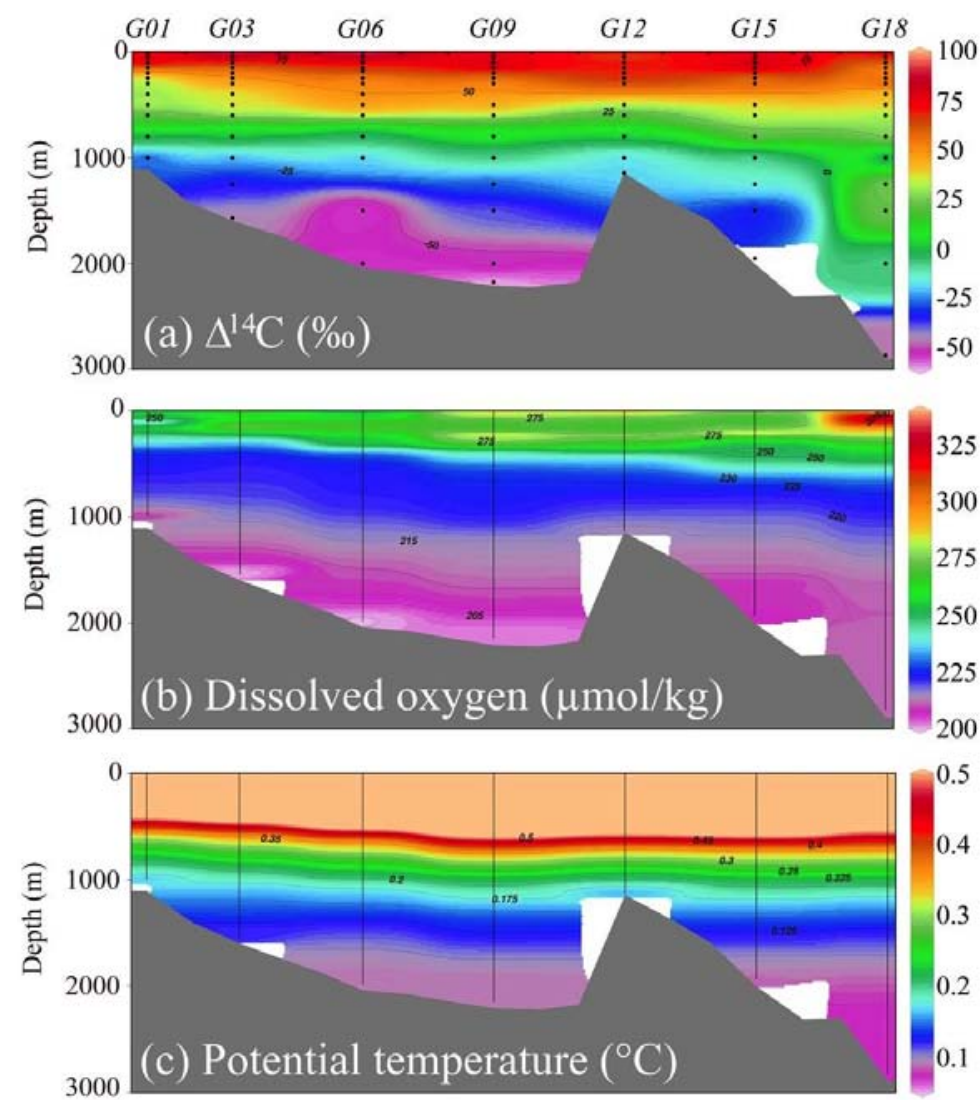

Figure 4 Meridional sections along $130.5^{\circ} \mathrm{E}$ of $\Delta^{14} \mathrm{C}$ (a), dissolved oxygen (b) and potential temperature (c). Filled circles in (a) indicate sampling depths. 


\section{T Aramaki et al.}

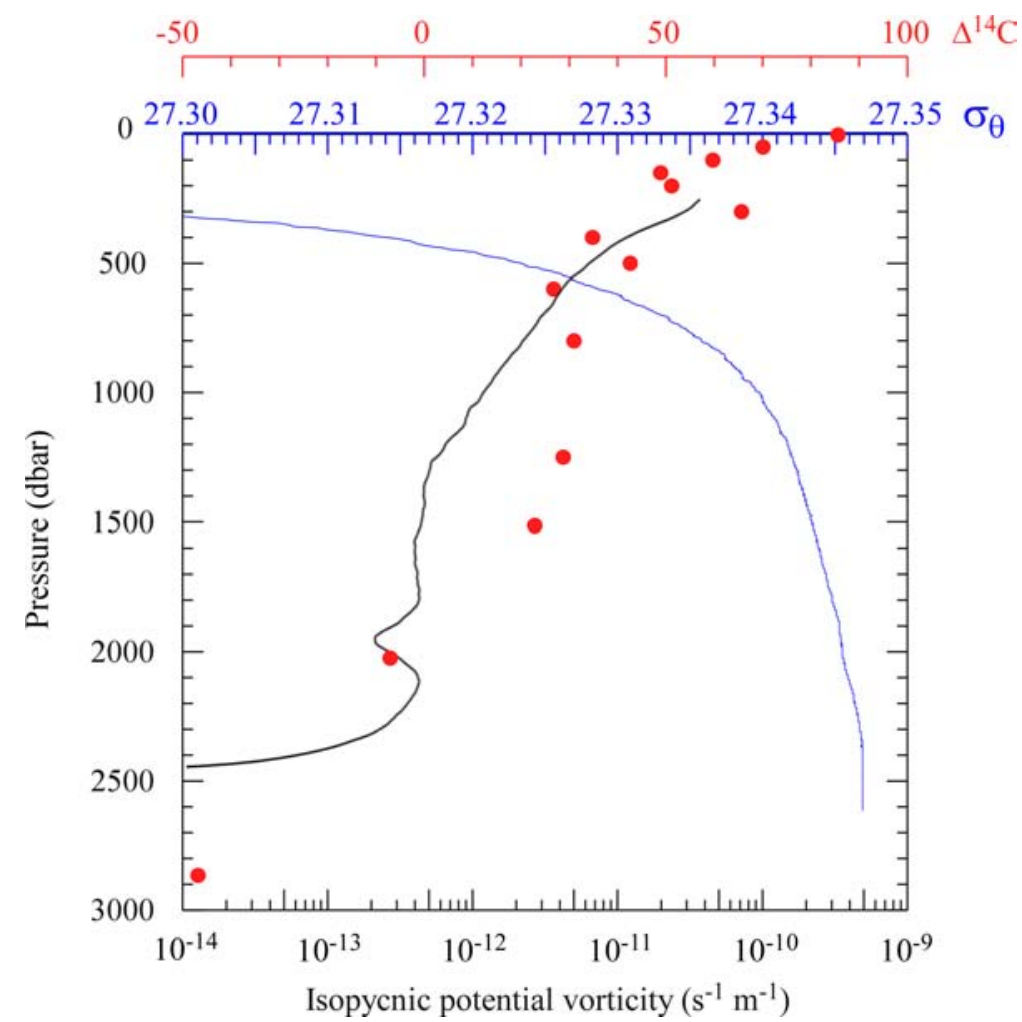

Figure 5 Vertical profiles of isopycnic potential vorticity $\left(\mathrm{s}^{-1} \mathrm{~m}^{-1}\right.$, black line), potential density ( $\mathrm{kg} \mathrm{m}^{-3}$, blue line), and $\Delta^{14} \mathrm{C}$ (\%, red circles).

There is, however, no evidence that the new bottom water formed in 2001 had been transported into the Tsushima/Ulleung Basin at the time of our observations. Because the Tsushima/Ulleung Basin is separated from the Japan Basin by a shallow sill near Ulleung Island (see Figures 2 and 4), deep/bottom water exchange between the Japan Basin and the Tsushima/Ulleung Basin occurs via the deep valley between Ulleung Island and the Take-Shima/Dok-do (Chang et al. 2009). The new bottom water formed in 2001 might therefore have veered to the east at the southern edge of the Japan Basin. Senjyu et al. (2005) have provided a schematic depiction of the abyssal circulation in the Japan/East Sea based on physical observations such as moored current-meter measurements (Figure 6). According to their depiction of the circulation, there is a southward flow from Vladivostok to Ulleung Island along the continental shelf. Thus, our explanation of bottom water circulation is consistent with physical observations.

In contrast, 3 months after our observations, there was an increase of dissolved oxygen concentrations and decrease of water temperatures in the bottom layer of the western Japan Basin (Figure 6) (Senjyu et al. 2002). The concentration of chlorofluorocarbon-11, which was measured in the same hydrographic survey, also increased near the bottom (Tsunogai et al. 2003). These changes were found only near the bottom (between the bottom and a depth $200 \mathrm{~m}$ above the bottom). In contrast, at station G18, which is farther from Vladivostok than their observation points, effects of new bottom water formation were observed 3 months earlier, from the surface to near the bottom. This may indicate that the new bottom water had been formed in an area further to the south, such as the coastal region adjacent to North Korea, and/or that the new bottom water observed at the southern 


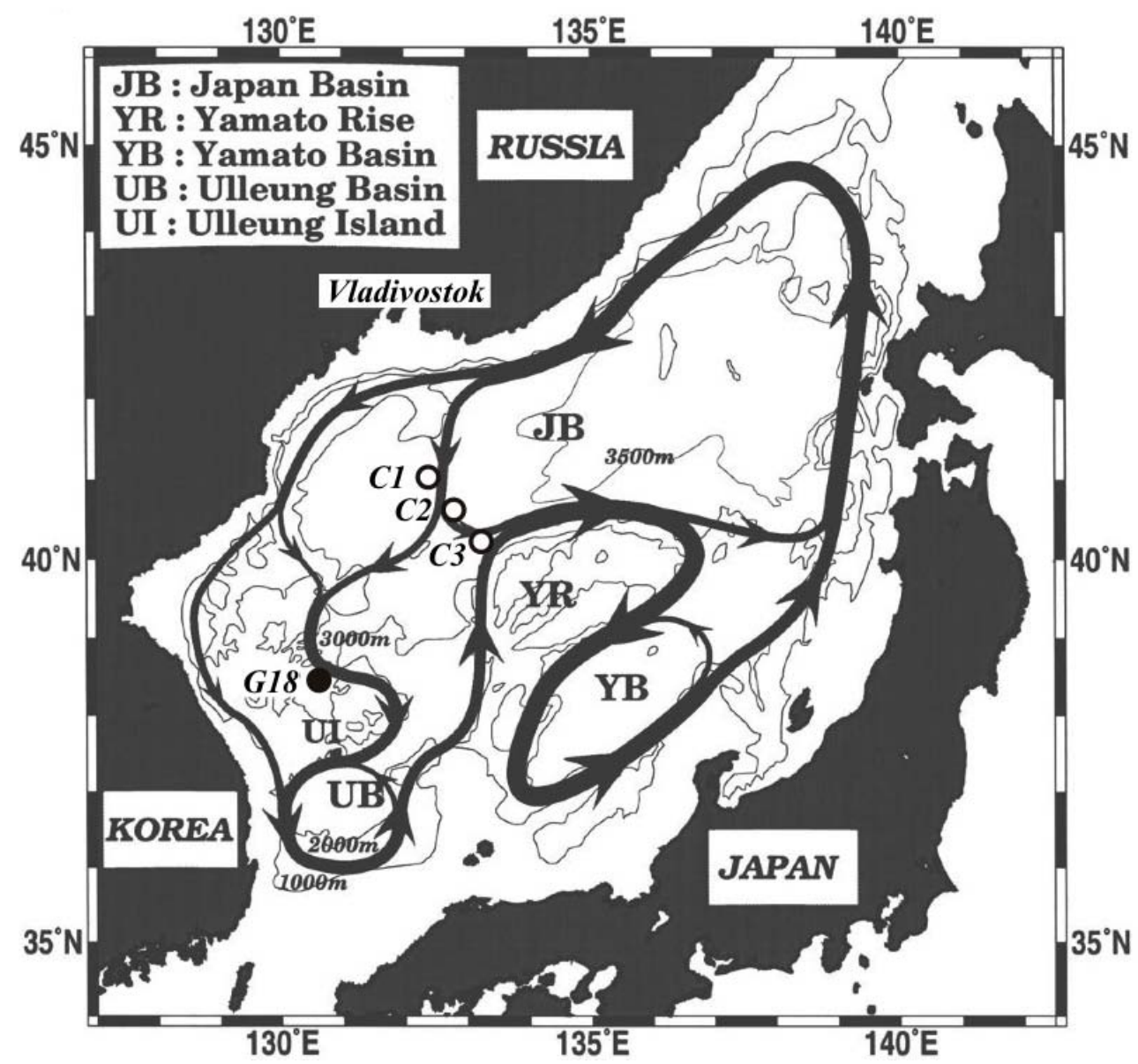

Figure 6 Schematic view of abyssal circulation in the Japan/East Sea based on physical observations (after Senjyu et al. 2005). Filled circle is our sampling station G18 and open circles are the observation points at which the water masses with low temperature, high oxygen, and high chlorofluorocarbon-11 were found near the bottom in July 2001 (Senjyu et al. 2002; Tsunogai et al. 2003).

edge of the Japan Basin had reached the western Japan Basin by counterclockwise circulation, with concomitant changes of properties. Otherwise, the origin and/or flow field of the new bottom water observed in the western Japan Basin might be different from those implied by our analysis.

\section{ACKNOWLEDGMENTS}

We thank the crew of the R/V Eardo and the staff of the Korea Ocean Research \& Development Institute (KORDI until 30 June 2012, Korea Institute of Ocean Science \& Technology [KIOST] since 1 July 2012) for their cooperation and help during the 2001 Japan/East Sea cruise. This work was supported by the Environment Research and Technology Development Fund of the Ministry of the Environment, Japan (A-1002) and the Korea Institute of Ocean Science \& Technology research project (PE98742). ${ }^{14} \mathrm{C}$ measurements for this work were performed under the Shared Use Program of Japan Atomic Energy Agency (JAEA) Facilities. 


\section{T Aramaki et al.}

\section{REFERENCES}

Aramaki T, Mizushima T, Mizutani Y, Yamamoto T, Togawa O, Kabuto S, Kuji T, Gottdang A, Klein M, Mous DJW. 2000. The AMS facility at the Japan Atomic Energy Research Institute (JAERI). Nuclear Instruments and Methods in Physics Research B 172(1-4):18-23.

Aramaki T, Senjyu T, Togawa O, Otosaka S, Suzuki T, Kitamura T, Amano H, Volkov YN. 2007. Circulation in the northern Japan Sea studied chiefly with radiocarbon. Radiocarbon 49(2):915-24.

Carpenter JH. 1965. The Chesapeake Bay Institute: technique for the Winkler dissolved oxygen method. Limnology and Oceanography 10:141-3.

Chang K-I, Kim K, Kim Y-B, Teague WJ, Lee JC, Lee JH. 2009. Deep flow and transport through the Ulleung Interplain Gap in the southwestern East/Japan Sea. Deep-Sea Research I 56:61-72.

Dickson AD. 1995. Determination of dissolved oxygen in sea water by Winkler titration. WOCE Operations Manual, Part 3.1.3 Operations \& Methods. WHP Office Report WHPO 91-1.

Gamo T. 1999. Global warming may have slowed down the deep conveyor belt of a marginal sea of the northwestern Pacific: Japan Sea. Geophysical Research Letters 26(20):3141-4.

Gamo T, Horibe Y. 1983. Abyssal circulation in the Japan Sea. Journal of the Oceanographical Society of Japan 39(5):220-30.

Gamo T, Nozaki Y, Sakai H, Nakai T, Tsubota H. 1986. Spatial and temporal variations of water characteristics in the Japan Sea bottom layer. Journal of Marine Research 44(4):781-93.

Key RM, Quay PD, Jone GA, McNichol AP, Von Reden KF, Schneider RJ. 1996. WOCE AMS radiocarbon I: Pacific Ocean results; P6, P16 \& P17. Radiocarbon 38(3):425-518.

Kim K, Kim K-R, Min D-H, Volkov Y, Yoon J-H, Takamatsu M. 2001. Warming and structural changes in the East (Japan) Sea: a clue to future changes in global oceans? Geophysical Research Letters 28(17):32936.

Kim K-R, Kim G, Kim K, Lobanov V, Ponomarev V, Salyuk A. 2002. A sudden bottom-water formation during the severe winter 2000-2001: the case of the East/Japan Sea. Geophysical Research Letters 29(8): doi:10.1029/2001GL014498.

Kitagawa H, Masuzawa T, Nakamura T, Matsumoto E. 1993. A batch preparation method of graphite targets with low background for AMS ${ }^{14} \mathrm{C}$ measurements. $\mathrm{Ra}$ - diocarbon 35(2):295-300.

Kumamoto Y, Yoneda M, Shibata Y, Kume H, Tanaka A, Uehiro T, Morita M, Shitashima K. 1998. Direct observation of the rapid turnover of the Japan Sea bottom water by means of AMS radiocarbon measurement. Geophysical Research Letters 25(5):651-4.

Kumamoto Y, Aramaki T, Watanabe S, Yoneda M, Shibata Y, Togawa O, Morita M, Shitashima K. 2008. Temporal and spatial variations of radiocarbon in Japan Sea Bottom Water. Journal of Oceanography 64(3):429-41.

Kwon Y-O, Kim K, Kim Y-G, Kim K-R. 2004. Diagnosing long-term trends of the water mass properties in the East Sea (Sea of Japan). Geophysical Research Letters 31(20): doi:10.1029/2004GL020881.

Minami H, Kano Y, Ogawa K. 1999. Long-term variations of potential temperature and dissolved oxygen of the Japan Sea Proper Water. Journal of Oceanography 55(2):197-205.

Östlund GH, Stuiver M. 1980. GEOSECS Pacific radiocarbon. Radiocarbon 22(1):25-53.

Senjyu T, Aramaki T, Otosaka S, Togawa O, Danchenkov M, Karasev E, Volkov Yu. 2002. Renewal of the bottom water after the winter 2000-2001 may spin-up the thermohaline circulation in the Japan Sea. Geophysical Research Letters 29(7): doi:10.1029/ $2001 G L 014093$.

Senjyu T, Shin H-R, Yoon J-H, Nagano Z, An H-S, Byun S-K, Lee C-K. 2005. Deep flow field in the Japan/East Sea as deduced from direct current measurements. Deep-Sea Research II 52(11-13):1726-41.

Stuiver M. 1983. International agreements and the use of the new oxalic acid standard. Radiocarbon 25(2):7935.

Stuiver M, Polach H. 1977. Discussion: reporting of ${ }^{14} \mathrm{C}$ data. Radiocarbon 19(3):355-63.

Suda K. 1932. On the bottom water in the Japan Sea (preliminary report). Journal of Oceanography 4:221-41. In Japanese.

Sudo H. 1986. A note on the Japan Sea Proper Water. Progress in Oceanography 17(3-4):313-36.

Talley LD, Pickard GL, Emery WJ, Swift JH. 2011. Descriptive Physical Oceanography: An Introduction. 6th Edition. Amsterdam: Elsevier. 555 p.

Tsunogai S, Kawada K, Watanabe S, Aramaki T. 2003. CFC indicating renewal of the Japan Sea Deep Water in winter 2000-2001. Journal of Oceanography 59(5):685-93. 